\title{
PENGENDALIAN PERSEDIAAN BAHAN BAKU TUMPI MENGGUNAKAN METODE ECONOMIC ORDER QUANTITY (EOQ) DAN METODE PERIOD ORDER QUANTITY (POQ) DI UD. JAYA ABADI SOLUTION
}

\author{
Erik Suyanto \\ Teknik Industri, Fakultas Teknik, Universitas Hasyim Asy’ari, Email : eriksuyanto99@gmail.com
}

\author{
Andhika Mayasari \\ Teknik Industri, Universitas Hasyim Asy’ari, Email : andhikamayasari@gmail.com \\ Nur Kholis \\ Fakultas Teknik, Universitas Hasyim Asy’ari, Email : nurkholis.unhasy@ yahoo.com
}

\section{Abstrak}

Perencanaan pengendalian kebutuhan bahan baku di dalam suatu perusahaan memanglah sangat penting dalam menjaga produktifitas dalam kegiatan berproduksi serta pengaruhnya terhadap biaya pengadaan barang. UD. Jaya Abadi Solution merupakan salah satu perusahaan yang memproduksi berbagai pakan ternak hasil limbah dari pabrik-pabrik pembuatan pakan ternak. Sering terjadi fluktuasi ketersediaan bahan baku untuk proses produksi terutama bahan baku tumpi yang mengakibatkan proses produksi tidak optimal. Tujuan penelitian ini yaitu untuk mengendalikan persediaan bahan baku tumpi dengan metode Economic Order Quantity dan metode Period Order Quantity serta mengetahui selisih biaya antara perhitungan perusahaan dengan perhitungan metode Economic Order Quantity (EOQ) dan metode Period Order Quantity (POQ). Metode yang dipakai dalam penelitian ini yaitu metode Economic Order Quantity (EOQ) dan metode Period Order Quantity (POQ), kedua metode ini diharapkan mampu mengatasi fluktuasi ketersediaan bahan baku tumpi. Berdasarkan hasil penelitian dengan metode Economic Order Quantity (EOQ) dan metode Period Order Quantity (POQ) menghasilkan nilai EOQ sebesar 220 ton dengan total biaya sebesar Rp. 113.165.509, sedangkan nilai POQ sebesar 205 ton dan biaya total sebesar Rp 113.285.546. Selisih biaya yang dihasilkan adalah sebesar $19 \%$ dibandingkan dengan total biaya perusahaan.

Kata Kunci : Economic Order Quantity, Period Order Quantity, Selisih Biaya

The controlling planning of raw material needs in a company is very important to keep productivity on production activityand its influence on the material procurement cost. UD. Jaya Abadi Solution is one of the company that produces various fodder from the waste of animal feed manufacturing factory. The fluctuation often happens in raw material availability for production process especially "tumpi" raw materialwhich causes the production process is not optimal. The purpose of the research is to control "tumpi" raw material availability by using Economic Order Quantity (EOQ) method and Period Order Quantity (POQ) methodand to know the different cost between the company calculation and EOQ and POQ methods caculations. The methods used in this research are Economic Order Quantity (EOQ) method and Period Order Quantity (POQ) method, these methods are expected to be able to cope the fluctuation of the "tumpi" raw material availability. Based on the result of the research using Economic Order Quantity (EOQ) method and Period Order Quantity (POQ) method yielded is EOQ value of 220 tons with total cost of Rp. 113.165.509, while POQ value is 205 tons with the total cost of Rp. 113.285.546. The different cost produced is $19 \%$ compared to the company total cost.

Key Words : Economic Order Quantity, Period Order Quantity, Different Cost

\section{PENDAHULUAN}

Pengendalian persediaan menjadi salah satu bagian terpenting dalam kelangsungan kegiatan operasional di semua perusahaan terutama perusahaan manufaktur. Ketersediaan material bahan baku yang mumpuni dapat membantu seorang manajer produksi dalam membuat rencana produksi yang sesuai dengan target yang dibebankan oleh perusahaan. UD. Jaya Abadi Solution merupakan salah satu perusahaan yang bergerak di bidang manufaktur, tepatnya dalam pengolahan kembali limbah pakan ternak dari pabrik pembuatan pakan ternak. Limbah pakan ternak itu berupa tumpi, bungkil sawit, bungkil kopra dan kulit kopi yang akan diolah kembali menjadi pakan sapi, ayam, itik, kambing dan bebek.

Salah satu permasalahan yang sedang dihadapi UD. Jaya Abadi Solution saat ini yaitu ketersediaan bahan baku terutama bahan baku tumpi ini sering mengalami fluktuasi dikarenakan beberapa sebab di antaranya spesifikasi dan kapasitas mesin produksi dari suplier itu ukurannya berbeda-beda yang 
pastinya mempengaruhi hasil produksi dan limbah yang dihasilkan, serta jumlah kuantitas produk yang dihasilkan juga berbeda, semakin besar jumlah kuantitas produksi yang dihasilkan semakin besar pula limbah yang dihasilkan dan begitu pun sebaliknya.

Untuk mengatasi hal tersebut, diperlukan suatu formula baru untuk memperbaiki sistem pengendalian persediaan bahan baku tumpi di UD. Jaya Abadi Solution. Perbaikan tersebut menyangkut beberapa hal yaitu penentuan jumlah kuantitas pemesanan guna mendapatkan jumlah pemesanan bahan baku yang optimal (tepat) setiap bulannya, besarnya nilai persediaan pengaman serta kapan bahan baku tersebut harus dipesan kembali dan berapa kali frekuensi pemesanan bahan baku tumpi dalam satu tahun yang dari komponenkomponen tersebut dapat membentuk satu nilai perhitungan biaya persediaan bahan baku tumpi yang paling minimum.

Berdasarkan latar belakang permasalahan di atas, yang menjadi rumusan untuk penelitian ini yaitu bagaimana mengendalikan persediaan bahan baku tumpi dengan metode Economic Order Quantity (EOQ) dan metode Period Order Quantity (POQ) di UD. Jaya Abadi Solution serta berapa selisih biaya antara perhitungan menurut perusahaan dengan perhitungan menurut metode Economic Order Quantity (EOQ) serta metode Period Order Quantity (POQ).

Output dari penelitian menggunakan metode Economic Order Quantity (EOQ) dan metode Period Order Quantity (POQ) ini yaitu perusahaan diharapkan mampu mengatasi keadaan fluktuasi akan ketersediaan bahan baku tumpi serta dapat meminimalkan biaya persediaan untuk pengadaan bahan baku tumpi.

\section{METODE}

Metode yang digunakan dalam penelitian ini adalah metode Economic Order Quantity (EOQ) dan metode Period Order Quantity (POQ). Penelitian ini dilakukan di UD. Jaya Abadi Solution yang terletak di di Dusun Sambikerep, Desa Pekukuhan, Kecamatan Mojosari, Kabupaten Mojokerto. Objek penelitian ini adalah ketersediaan bahan baku tumpi yang mengalami fluktuasi. Langkah-langkah penyelesaian masalah dalam penelitian ini yaitu sebagai berikut :
Latar Belakang

Bahan baku tumpi yang diperoleh dari pabrik-pabrik pembuatan pakan ternak terkadang persediaannya cukup banyak namun pada suatu periode tertentu persediaan bahan baku tumpi tersebut juga mengalami kekurangan persediaan yang berakibat pada kegiatan produksi UD. Jaya Abadi Solution menjadi kurang optimal. Kurang optimalnya persediaan bahan baku tumpi ini dapat mempengaruhi dalam penentuan berapa jumlah bahan baku yang harus dipesan, persediaan pengaman serta kapan bahan baku tersebut dipesan kembali yang nantinya akan mempengaruhi biaya persediaan tumpi yang harus dikeluarkan oleh UD. Jaya Abadi Solution.
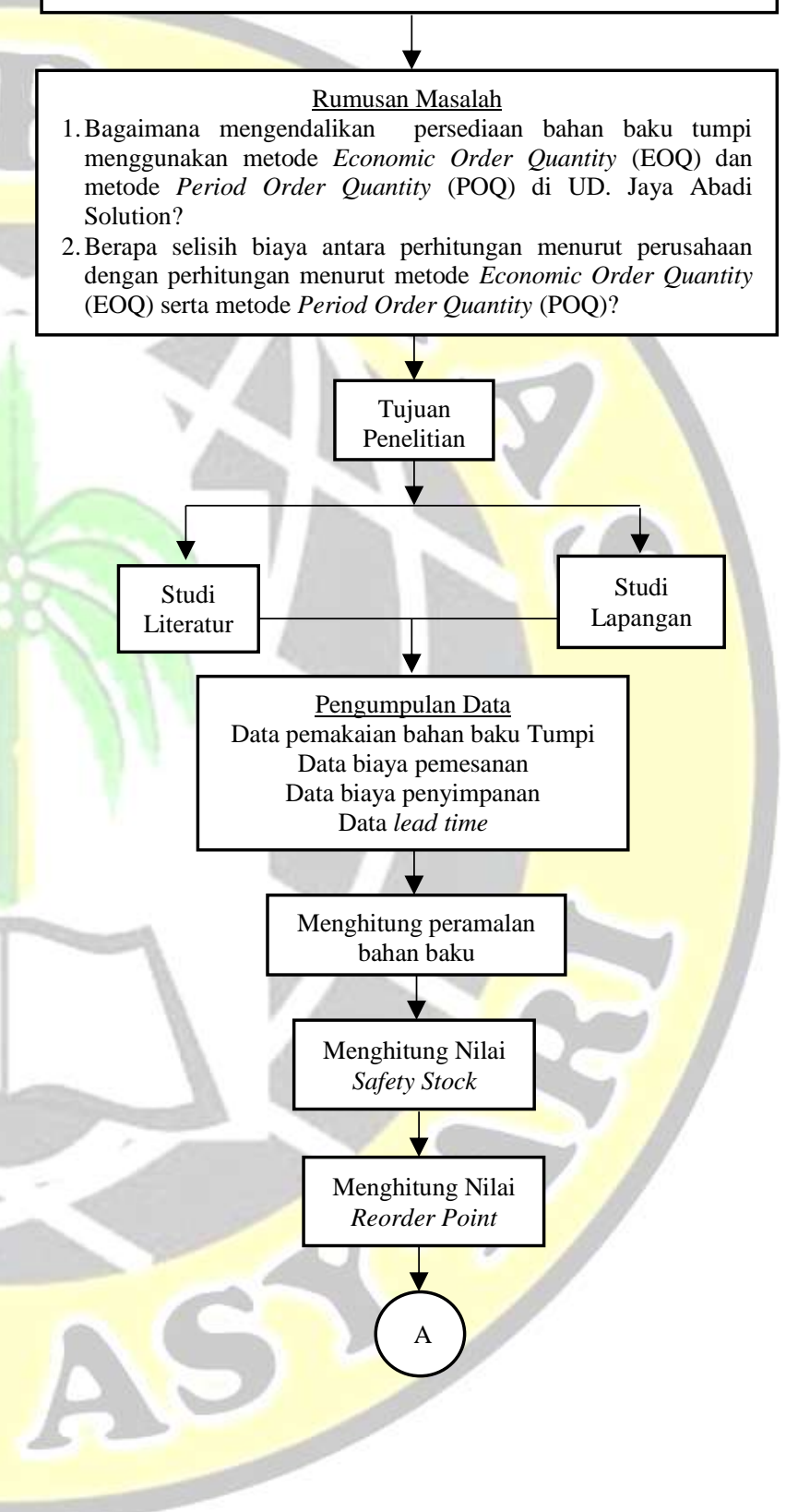

\author{
.
}




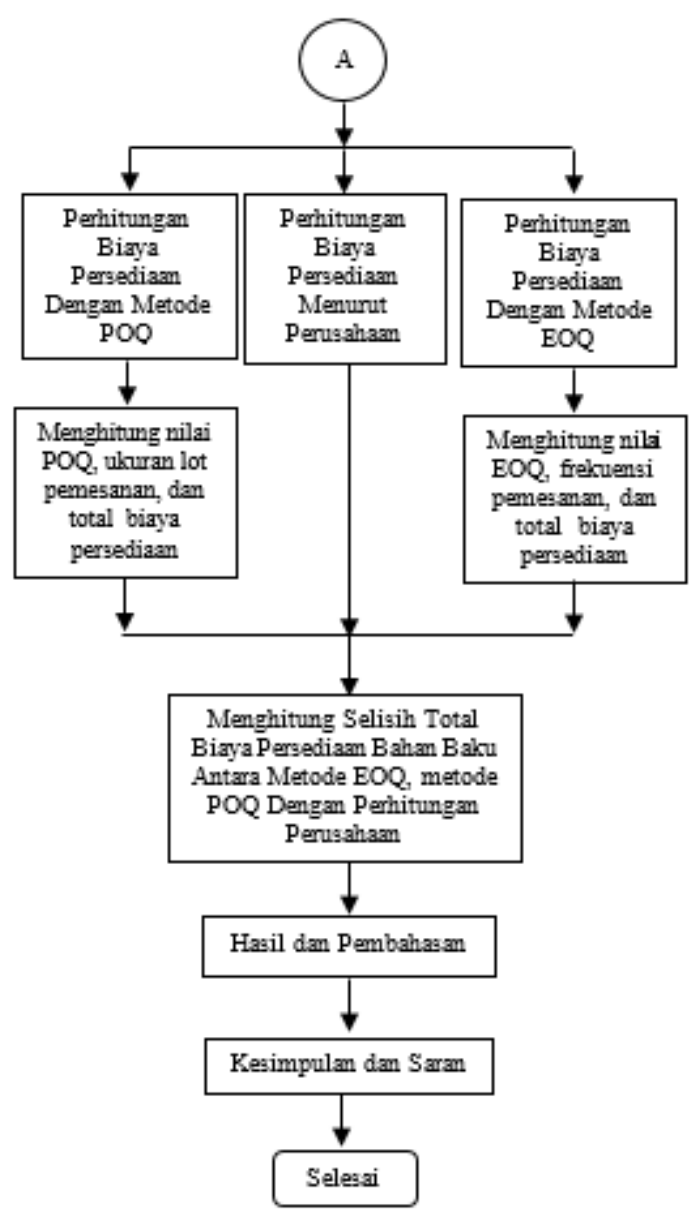

Gambar 1. Langkah-Langkah Penelitian

Teknik pengumpulan data yang digunakan dalam penelitian ini adalah sebagai berikut :

1. Data primer adalah data-data dalam penelitian yang diperoleh secara langsung dari lapangan oleh narasumber melalui observasi dan wawancara. Ada 2 metode dalam pengumpulan data primer yaitu observasi dan wawancara.

2. Data sekunder dapat berupa dokumen-dokumen penunjang. Adapun dokumen yang diambil dari lokasi penelitian yaitu data pemakaian tumpi, data-data biaya pemesanan, biaya penyimpanan dan data lead time.

Pengolahan data yang digunakan pada penelitian ini ada 2 yaitu pengendalian persediaan bahan baku menggunakan metode EOQ dan metode POQ serta perbandingan selisih antara hasil perhitungan perusahaan dengan hasil perhitungan menggunakan metode Economic Order Quantity (EOQ) dan metode Period Order Quantity (POQ)

\section{HASIL DAN PEMBAHASAN}

Pada bagian ini akan disajikan beberapa data yang sudah dikumpulkan selama melaksanakan penelitian di UD. Jaya Abadi Solution.

Data historis pemakaian bahan baku tumpi dapat dilihat pada Gambar 2. :

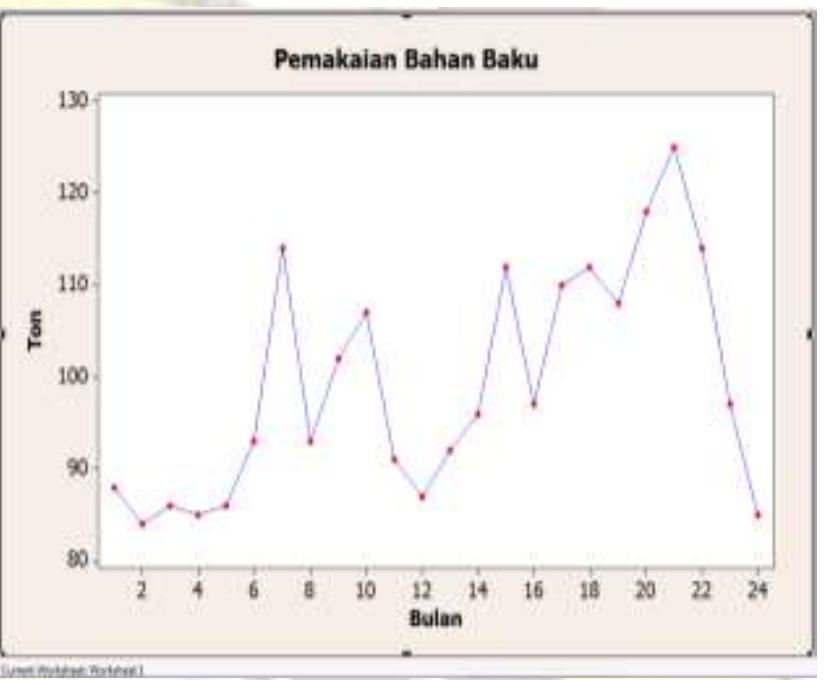

Gambar 2. Data Historis Pemakaian Bahan Baku

Adapun 2 data biaya yaitu biaya pemesanan dan biaya penyimpanan yaitu sebagai berikut :

1. Biaya pemesanan untuk pengadaan bahan baku tumpi dapat dilihat pada tabel 1. di bawah ini :

Tabel 1. Biaya Pemesanan $(1$ Tahun $=12$ bulan $)$

\begin{tabular}{|c|c|c|}
\hline $\begin{array}{c}\text { Biaya } \\
\text { Pemesanan }\end{array}$ & $\begin{array}{c}\text { Jumlah/Bula } \\
\text { n (Rp) }\end{array}$ & $\begin{array}{c}\text { Jumlah/Tahun } \\
\text { (Rp) }\end{array}$ \\
\hline $\begin{array}{ll}\text { a. } & \text { Ongkos } \\
\text { administrasi }\end{array}$ & Rp. 20.000 & Rp. $\quad 240.000$ \\
\hline $\begin{array}{l}\text { b. Ongkos } \\
\text { telpon }\end{array}$ & Rp. 100.000 & Rp. 1.200 .000 \\
\hline $\begin{array}{ll}\text { c. } & \text { Biaya } \\
\text { distribusi } \\
\text { - Ongkos } \\
\text { sopir } \\
\text { - Ongkos } \\
\text { makan }\end{array}$ & $\begin{array}{l}\text { Rp. } 380.000 \\
\text { Rp. } 80.000\end{array}$ & $\begin{array}{l}\text { Rp. } 4.560 .000 \\
\text { Rp. } 960.000\end{array}$ \\
\hline $\begin{array}{ll}\text { d. } & \text { Biaya } \\
\text { lainnya } \\
\text { - BBM } \\
\text { - Uang tol } \\
\text { - Parkir }\end{array}$ & $\begin{array}{lr}\text { Rp. } & 200.000 \\
\text { Rp. } & 16.000 \\
\text { Rp. } & 15.000\end{array}$ & $\begin{array}{lr}\text { Rp. } & 2.400 .000 \\
\text { Rp. } & 192.000 \\
\text { Rp. } & 180.000\end{array}$ \\
\hline TOTAL & Rp. 811.000 & Rp. 9.732.000 \\
\hline
\end{tabular}

(Sumber : UD. Jaya Abadi Solution, 2018) 
2. Presentase biaya simpan untuk bahan baku tumpi dapat dilihat pada tabel 2. di bawah ini :

Tabel 2. Biaya Simpan

\begin{tabular}{llcc}
\hline Bahan & & Presentase & Nilai \\
Baku & Harga & Biaya Simpan & Presentase \\
& $\begin{array}{l}\text { Bahan Baku } \\
\text { (Ton) }\end{array}$ & bulan) & $\begin{array}{c}\text { Biaya } \\
\text { Simpan per } \\
\text { Tahun }\end{array}$ \\
\hline Tumpi & Rp. 500.000 & Rp. 40.000 & Rp. 480.000
\end{tabular}

(Sumber : UD. Jaya Abadi Solution, 2018)

Data lead time atau waktu pemesanan bahan baku tumpi sampai bahan baku tersebut datang adalah sebagai berikut :

Tabel 3. Data Lead Time Pemesanan

\begin{tabular}{cc}
\hline $\begin{array}{c}\text { Supplier Bahan } \\
\text { Baku Tumpi }\end{array}$ & Lead Time (hari) \\
\hline PT. X & 2 \\
\hline PT. XY & 2 \\
\hline PT. Z & 2 \\
\hline PT. ZX & 3 \\
\hline PT. ZY & 1 \\
\hline Rata-rata lead time & 2 \\
\hline (Sumber : UD J Jaya Abadi Solution, 2018)
\end{tabular}

(Sumber : UD. Jaya Abadi Solution, 2018)

Berdasarkan data lead time di atas, waktu antara pemesanan sampai bahan baku tumpi datang sampai ke UD. Jaya Abadi Solution yaitu membutuhkan waktu rata-rata 2 hari.

Pengolahan data dalam penelitian ini terbagi menjadi beberapa tahapan, tahapan tersebut yaitu sebagai berikut :

Berdasarkan Gambar 2. diperoleh jumlah data historis pemakaian bahan baku tumpi selama 1 tahun sebesar 1191 ton, sehingga :

$Q=\frac{\text { Pemakaian } 1 \text { tahun }}{12 \text { bulan }}=\frac{1191}{12}=99,25 \equiv 100$ ton

Total biaya perusahaan untuk persediaan bahan baku

= biaya pemesanan + biaya simpan

$=\frac{1191}{100} \times$ Rp. $9.732 .000+\frac{100}{2} \times$ Rp. 480.000

$=$ Rp. $115.908 .120+$ Rp. 24.000 .000

$=$ Rp. 139.908 .120
Hasil Peramalan Metode Regresi Linier Menggunakan Software Minitab

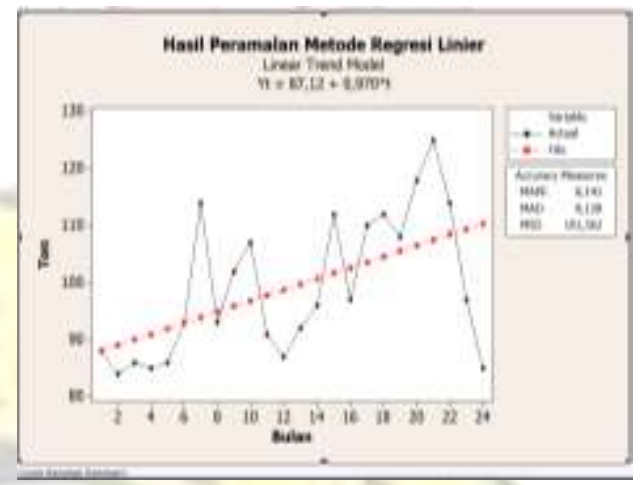

Gambar 3. Hasil Peramalan Metode Regresi Linier

Hasil Peramalan Metode Moving Average Menggunakan Software Minitab

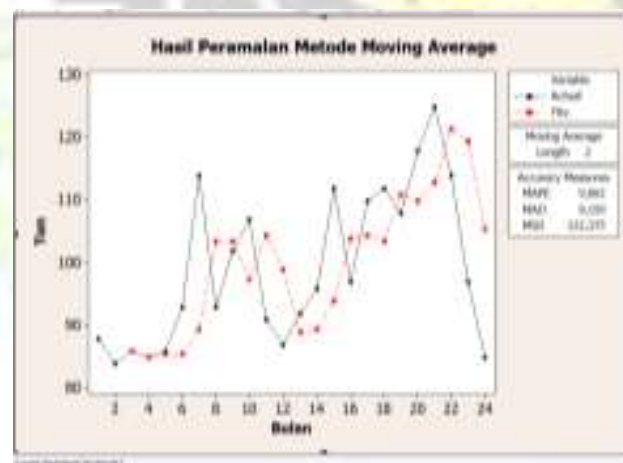

Gambar 4. Hasil Peramalan Metode Moving Average

Hasil Peramalan Metode Single Exponential Smoothing Menggunakan Software Minitab

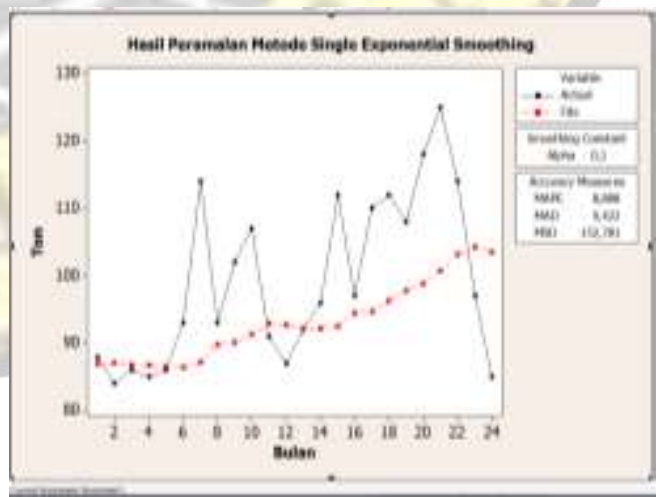

Gambar 5. Hasil Peramalan Metode Single Exponential Smoothing 
Ploting 3 Hasil Peramalan Dibandingkan Dengan Data Aktual

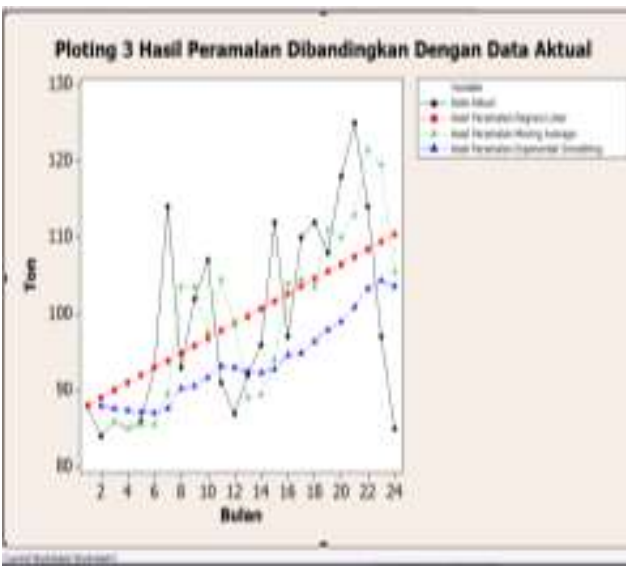

Gambar 6. Ploting 3 Hasil Peramalan Dibandingkan Dengan Data Aktual

Perhitungan Nilai MAD, MSE, dan MAPE Untuk Metode Regresi Linier, Moving Range dan Exponential Smoothing

Tabel 4. Nilai MAD, MSE, dan MAPE Tumpi

\begin{tabular}{ccccc}
\hline No. & Metode & MAD & MSE & MAPE \\
\hline 1. & Regresi Linier & 8,128 & 101,562 & 8,141 \\
\hline 2. & Moving Average & 9,159 & 132,375 & 9,062 \\
\hline 3. & $\begin{array}{c}\text { Exponential } \\
\text { Smoothing }\end{array}$ & 9,422 & 152,781 & 8,888 \\
\hline
\end{tabular}

(Sumber : Pengolahan Data, 2018)

Dari grafik pada gambar 6. dan tabel 4. di atas, dapat disimpulkan bahwa hasil peramalan dengan metode regresi linier lebih konsisten dibandingkan 2 metode lainnya dikarenakan menghasilkan nilai MAD, MAPE dan MSE yang paling kecil, maka dari itu hasil permalan yang terpilih adalah menggunakan metode regresi linier.

Penggunaan Peta Moving Range ini berfungsi untuk mengetahui atau mengukur apakah hasil peramalan yang sudah dipilih dalam keadaan stabil secara statistik atau tidak, kemudian setelah dilakukan perhitungan menghasilkan nilai MR, Batas Kontrol Atas (BKA), dan Batas Kontrol Bawah (BKB) sebesar :

$M R=\frac{\Sigma M R}{n-1}=\frac{204,0887}{23}=8,873$

$\mathrm{BKA}=+2,66 \times \mathrm{MR}=+2,66 \times 8,873=23,603$

$\mathrm{BKB}=-2,66 \times \mathrm{MR}=-2,66 \times 8,873=-23,603$

Dari perhitungan di atas, selanjutnya akan digambarkan peta Moving Range berupa grafik untuk peramalan kebutuhan bahan baku, grafik peta Moving Range tumpi dapat dilihat pada gambar 7. berikut ini :

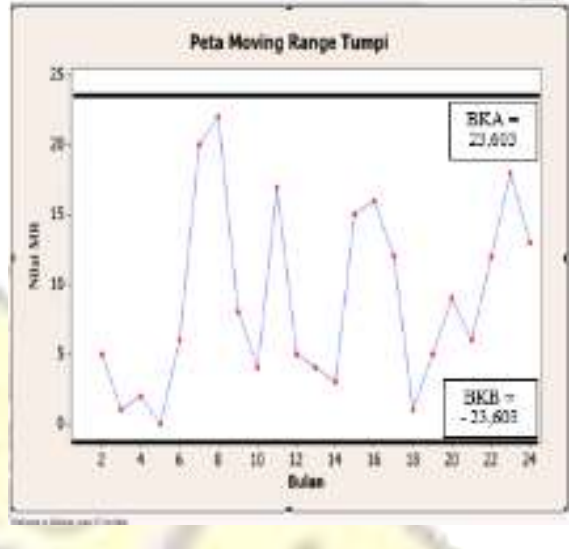

Gambar 7. Grafik Peta Moving Range Tumpi

Berdasarkan peta kendali pada gambar 7. di atas, terlihat bahwa tidak ada hasil peramalan yang melewati BKA maupun BKB, secara otomatis dapat disimpulkan bahwa peramalan linier di atas adalah valid.

Dengan menggunakan tingkat pelayanan yaitu sebesar $95 \%$, dapat disimpulkan bahwa resiko terjadinya kekurangan persediaan bahan baku adalah $5 \%$, dengan data loss sebesar $5 \%$, maka tabel kurva normal didapatkan sebesar $\mathrm{z}=1,65$.

Perhitungan persediaan pengaman (safety stock) untuk periode selanjutnya adalah sebagai berikut :

$S D=\sqrt{\frac{\sum(x-x i)}{N-1}}=\sqrt{\frac{1083}{23}}=\sqrt{47,087}=6,862$ ton

Setelah diketahui nilai dari standar deviasi, maka langkah selanjutnya adalah menghitung nilai safety stock dengan nilai lead time $=2$, perhitungannya adalah sebagai berikut :

$$
\begin{aligned}
\mathrm{SS} & =\mathrm{Z} \times \mathrm{SD} \times \sqrt{L} \\
& =1,65 \times 6,862 \times \sqrt{2} \\
& =16,012 \text { ton } \\
& \equiv 16 \text { ton }
\end{aligned}
$$

Perhitungan reorder point bertujuan untuk mengetahui pada level berapa pemesanan kembali dilakukan berdasarkan persediaan yang ada. Adapun perhitungan reorder point untuk kebutuhan bahan baku tumpi pada periode selanjutnya yaitu sebagai berikut :

$$
\begin{aligned}
\mathrm{L} & =\frac{2 \text { hari }}{30 \text { hari }}=0,067 \\
\mathrm{RP} & =\mathrm{SS}+\mathrm{LD} \\
& =16+(0,067 \times 2382 / 24) \\
& =22,661 \text { ton } \\
& \equiv 23 \text { ton }
\end{aligned}
$$

Perhitungan untuk nilai EOQ, frekuensi pemesanan dan total biaya persediaan menggunakan metode Economic Order Quantity (EOQ) adalah sebagai berikut : 
$D=\frac{2382 \text { ton }}{2 \text { tahun }}=1191$ ton $/$ tahun

$$
\begin{aligned}
E O Q & =\sqrt{\frac{2 \cdot S \cdot D}{H}} \\
& =\sqrt{\frac{2 \times 9.732 .000 \times 1191}{480.000}} \\
& =219,761 \equiv 220 \text { ton }
\end{aligned}
$$

Frekuensi pemesanan dalam 1 tahun :

$f=\frac{D}{Q}=\frac{1.191}{220}=5,413 \equiv 6 \mathrm{kali}$

Total biaya persediaan menurut metode EOQ :

$$
\begin{aligned}
\text { TIC } & =\frac{k \cdot D}{Q}+\left(S S+\frac{Q}{2}\right) \cdot h \\
& =\frac{R p .9 .732 .000 \times 1.191}{220}+\left(16+\frac{220}{2}\right) \times
\end{aligned}
$$

Rp. 480.000

$$
\begin{aligned}
& =R p .52 .685 .509+R p .60 .480 .000 \\
& =R p .113 .165 .509
\end{aligned}
$$

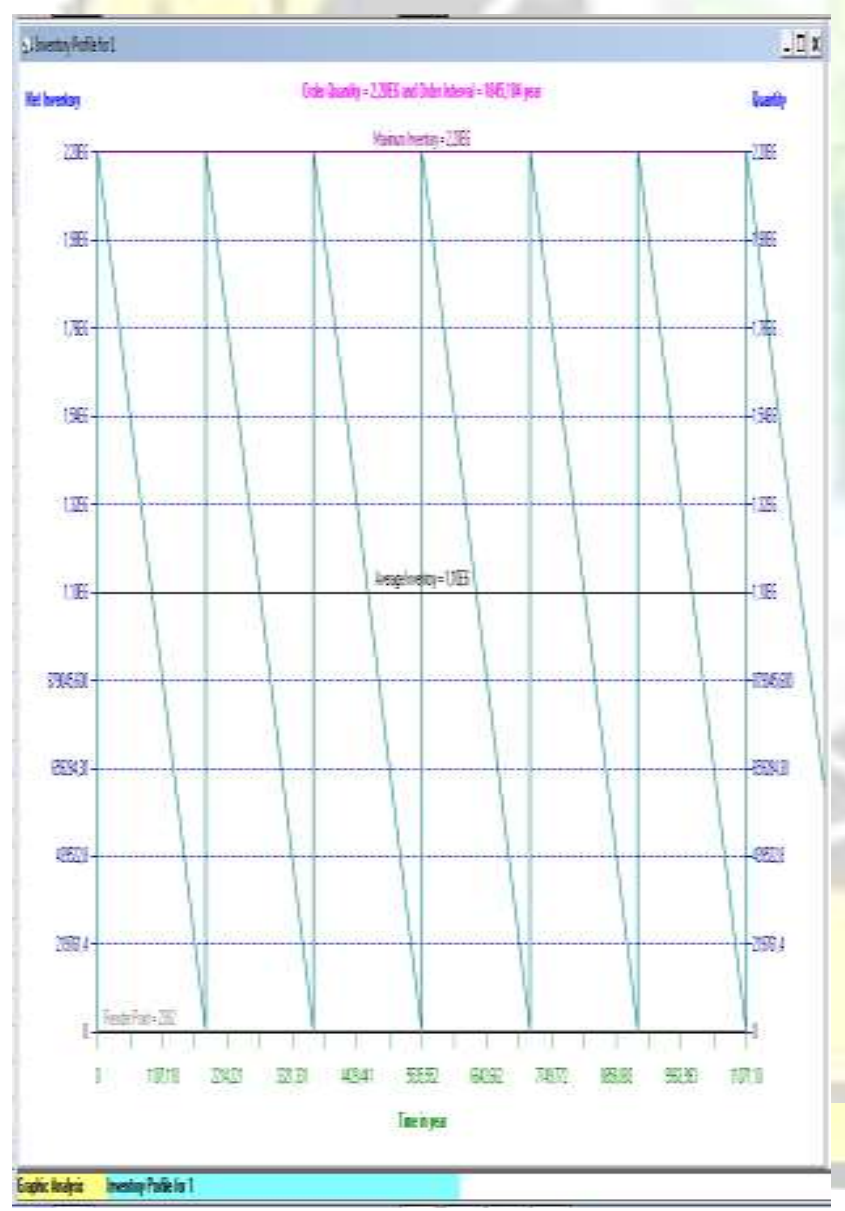

Gambar 8. Grafik EOQ

Berdasarkan hasil perhitungan dan gambar 8. di atas, didapatkan ukuran untuk sekali pesan adalah sebesar 220 ton dan frekuensi pemesanan dalam 1 tahun adalah sebanyak 6 kali dan total biaya persediaan menurut metode EOQ adalah sebesar Rp. 113.165.509.

Perhitungan untuk nilai POQ, frekuensi pemesanan dan total biaya persediaan menggunakan metode Period Order Quantity (POQ) adalah sebagai berikut :

$$
\begin{aligned}
E O I=\frac{E O Q}{R} & =\sqrt{\frac{2 \cdot C}{R \cdot P \cdot h}} \\
& =\sqrt{\frac{2 \times 9.732 .000}{100 \times 500.000 \times 0,08}}=2,205 \equiv 2
\end{aligned}
$$

Berdasarkan interval pemesanan EOI $=2$ di atas, maka dapat dihitung jumlah pemesanan dan periode waktu pemesanan adalah sebagai berikut :

Tabel 5. Ukuran Pemesanan Dalam 1 Tahun

\begin{tabular}{ccccccccccccc}
\hline Periode & 1 & 2 & 3 & 4 & 5 & 6 & 7 & 8 & 9 & 10 & 11 & 12 \\
\hline $\begin{array}{c}\text { Jumlah } \\
\text { (ton) }\end{array}$ & 172 & 0 & 193 & 0 & 194 & 0 & 199 & 0 & 224 & 0 & 211 & 0 \\
\hline
\end{tabular}

(Sumber : Pengolahan Data, 2018)

Keterangan dari Tabel 5. di atas yaitu sebagai berikut :

a. Nilai 172 ton berasal dari penjumlahan data historis pemakaian bahan baku tumpi yaitu $\frac{172 \text { ton }+171 \text { ton }}{2}=171,5 \equiv 172$ ton .

b. Nilai 193 ton berasal dari penjumlahan data historis pemakaian bahan baku tumpi yaitu $\frac{179 \text { ton }+207 \text { ton }}{2}=193$ ton .

c. Nilai 194 tonberasal dari penjumlahan data historis pemakaian bahan baku tumpi yaitu $\frac{209 \text { ton }+178 \text { ton }}{2}=193,5 \equiv 194$ ton.

d. Nilai 199 ton berasal dari penjumlahan data historis pemakaian bahan baku tumpi yaitu $\frac{188 \text { ton }+209 \text { ton }}{2}=198,5 \equiv 199$ ton .

e. Nilai 224 ton berasal dari penjumlahan data historis pemakaian bahan baku tumpi yaitu $\frac{222 \text { ton }+226 \text { ton }}{2}=224$ ton .

f. Nilai 211 ton berasal dari penjumlahan data historis pemakaian bahan baku tumpi yaitu $\frac{239 \text { ton }+182 \text { ton }}{2}=210,5 \equiv 211$ ton .

Berdasarkan Tabel 5., dapat disimpulkan bahwa pemesanan bahan baku tumpi harus dilakukan selama 6 kali dalam 1 tahun.

Ukuran lot pemesanan :

$$
E=\frac{R i(W+L)}{N}=\frac{1.191(2+0,067)}{12}=205,14
$$


Total biaya persediaan menurut metode POQ :

$$
\begin{aligned}
T I C & =\frac{k \cdot D}{Q}+\left(S S+\frac{Q}{2}\right) \cdot h \\
& =\frac{R p .9 .732 .000 \times 1.191}{205}+\left(16+\frac{205}{2}\right) \times \\
R p . & 480.000 \\
& =R p .56 .405 .546+R p .56 .880 .000 \\
& =R p .113 .285 .546
\end{aligned}
$$

Setelah diketahui hasil perhitungan menggunakan metode EOQ serta metode POQ pada di atas, maka langkah selanjutnya adalah melakukan perhitungan untuk perbandingan selisih biaya yang dihasilkan antara perhitungan dengan metode EOQ dan metode POQ. Total biayanya yaitu sebagai berikut : Total biaya persediaan menurut metode EOQ :

$$
\begin{aligned}
\text { TIC } & =\frac{k \cdot D}{Q}+\left(S S+\frac{Q}{2}\right) \cdot h \\
& =\frac{R p .9 .732 .000 \times 1.191}{220}+\left(16+\frac{220}{2}\right) \times
\end{aligned}
$$

Rp. 480.000

$$
\begin{aligned}
& =R p .52 .685 .509+R p .60 .480 .000 \\
& =R p .113 .165 .509
\end{aligned}
$$

Total biaya persediaan menurut metode POQ :

$$
\begin{aligned}
& \text { TIC }=\frac{k \cdot D}{Q}+\left(S S+\frac{Q}{2}\right) \cdot h \\
& \quad=\frac{R p .9 .732 .000 \times 1.191}{205}+\left(16+\frac{205}{2}\right) \times \\
& \text { Rp. } 480.000 \quad=R p .56 . \\
& \text { Rp. } 56.880 .000 \\
& \quad=R p .113 .285 .546
\end{aligned}
$$

Tabel 6. Perbandingan Selisih Biaya

\begin{tabular}{ccc} 
Total & Metode EOQ & Metode POQ \\
\cline { 2 - 3 } Biaya & Rp. 113.165.509 & Rp. 113.285.546
\end{tabular}

(Sumber : Pengolahan Data, 2018)

Berdasarkan Tabel 6. di atas, perhitungan yang menghasilkan biaya yang paling kecil adalah perhitungan dengan metode EOQ, ini berarti metode EOQ akan dijadikan sebagai prosentase dalam penghematan terhadap biaya perusahaan.

Prosentase Penghematan Biaya Perusahaan Dengan Metode EOQ

$$
\begin{aligned}
P & =\frac{\text { Total Biaya Perusahaan-Total Biaya EOQ }}{\text { Total Biaya Perusahaan }} \times 100 \% \\
& =\frac{R p .139 .908 .120-\text { Rp.113.165.509 }}{R p .139 .908 .120} \times 100 \% \\
& =19,11 \% \\
& \equiv 19 \%
\end{aligned}
$$

Dari hasil perhitungan di atas, diperoleh prosentase penghematan biaya persediaan bahan baku tumpi sebesar $19 \%$ menggunakan metode EOQ, dengan demikian dapat disimpulkan bahwa metode Economic Order Quantity (EOQ) dapat memberikan solusi terbaik dengan menghasilkan total biaya persediaan yang lebih rendah dari total biaya persediaan yang dihasilkan oleh perusahaan.

\section{KESIMPULAN}

Berdasarkan hasil penelitian dan pembahasan yang telah diperoleh, maka dapat disimpulkan bahwa :

1. Jumlah pemesanan paling optimal menggunakan metode Economic Order Quantity (EOQ) sebesar 220 ton dengan frekuensi pemesanan sebanyak 6 kali dalam 1 tahun dan total biaya persediaan yang dihasilkan adalah sebesar Rp. 113.165.509. Sedangkan dengan perhitungan menggunakan metode Period Order Quantity (POQ) menghasilkan jumlah pemesanan sebesar 205 ton, sementara frekuensi pemesanan juga sama dengan metode EOQ yaitu sebanyak 6 kali dalam satu tahun serta total biaya persediaan sebesar Rp. 113.285.546.

2. Total biaya persediaan yang dihasilkan oleh metode Economic Order Quantity (EOQ) lebih kecil daripada total biaya persediaan yang dihasilkan oleh metode Period Order Quantity (EOQ), dengan demikian total biaya persediaan metode EOQ akan dijadikan pembanding (selisih) dengan perhitungan total biaya menurut perusahaan. Setelah dilakukan perbandingan tersebut menghasilkan penghematan biaya persediaan sebesar $19 \%$.

\section{SARAN}

Dari kesimpulan yang telah dipaparkan di atas, maka saran yang dapat diberikan adalah sebagai berikut :

Diharapkan para pembaca penelitian ini dapat mengembangkan penelitian ini lebih lanjut seperti ada penambahan variabel baru, penggunaan metode baru yang lebih presisi dalam perhitungannnya dan penggunaan software baru yang lebih canggih.

\section{DAFTAR PUSTAKA}

Fithri, Prima \& Sindikia, Annise. 2014. "Pengendalian Persediaan Pozzolan di PT. Semen Padang". Jurnal Teknik Industri. Padang: Fakultas Teknik Universitas Andalas. http://repo.unand.ac.id/4588/6/Pengendalian $\% 20$ Persediaan\%20Pozzolan\%20di\%20PT\% 20Semen $\% 20$ Padang.pdf. Diakses pada tanggal 6 Maret 2018.

Gaspersz, Vincent. 1998. "Production Planning and Inventory Control”. Jakarta: PT. Gramedia Pustaka Utama.

Ghani, S. R. (2016). Analisa Potensi Sampah Kampus Berbasis Pemodelan Maket di 
Gedung B Unhasy. Rekayasa Keteknikan dan Optimasi 1 (1)| vol: | issue : |.

Ghani, S. R. (2011). Analisis Perbaikan UKM X Dengan Pendekatan Lean Manufacture Guna Mereduksi Waste di Lantai Produksi Alumunium. Rekayasa 4 (2)| vol: | issue : |, 119-124.

Ghani, S. R. (2011). Identitas Kerusakan Sarana dan Prasarana Dengan FMEA Guna Mengetahui Nilai Resiko dan Merencanakan Perawatan yang Optimal. Sistem 7 (1)| vol: | issue : |.

Ghani, S. R. (2017). Pattern Analysis of Cluster and Market Orientation (Religious Tour Area of Gus Dur's Grave). Proceedings of the International Conference on Green Technology 1 (1), | vol: | issue : |, 8-16.

Ghani, S. R. (2017). Perancangan dan Pengembangan Produk Alat Potong Sol Sandal. Teknika: Engineering and Sains Journal 1 (1), | vol: | issue : |, 73-76.

Handoko, T. Hani.1984. "Dasar-Dasar Manajemen Produksi dan Operasi". Yogyakarta: Penerbit BPFE-Yogyakarta.

Heizer, J. \& Render, B. 2010. "Manajemen Operasi”. Jakarta: Penerbit Salemba Empat.

Maharani, Mayora Hayundra. 2015. "Perbandingan Sistem Economic Order Quantity dan Just In Time Pada Pengendalian Persediaan Bahan Baku (Studi Kasus Pada CV. Aneka Ilmu Semarang)". Laporan Skripsi. Semarang: Fakultas Ekonomika dan Bisnis Universitas Diponegoro.

http://eprints.undip.ac.id/45671/1/11_MAHA

RANI.pdf. Diakses pada tanggal 12 Maret 2018.

Murty, Dita Harry. 2015. “Optimasi Pengendalian Persediaan Bahan Baku di PT. Bromindo Mekar Mitra". Laporan Tugas Akhir. Semarang: Fakultas Teknik Universitas Dian Nuswantoro.

http://mahasiswa.dinus.ac.id/docs/skripsi/leng kap/16243.pdf. Diakses pada tanggal 28 Februari 2018.

Nasution, Arman Hakim.2003. "Perencanaan dan Pengendalian Produksi". Surabaya: Penerbit Guna Widya.
Ristono, Agus. 2013. "Manajemen Persediaan". Yogakarta: Penerbit Graha Ilmu.

Sutarti, dkk. 2016. “Analisis Pengendalian Persediaan Bahan Baku Menggunakan Metode EOQ Dalam Upaya Meningkatkan Efisiensi (Studi Kasus Pada PT. Pancaran Mulia Sejati)". Jurnal Teknologi dan Manajemen Industri, Vol. 2 No. 2, Agustus 2016. Pasca Sarjana Institut Teknologi Nasional Malang. http://ejournal.itn.ac.id/index.php/jtmi/article/ download/301/242/. Diakses pada tanggal 12 maret 2018.

Wignjosoebroto, Sritomo.2003. "Pengantar Tenik dan Manajemen Industri”. Surabaya: Penerbit Guna Widya.

Yamit, Zulian. 2005. "Manajemen Persediaan". Yogyakarta: Penerbit Ekonosia FE.VII. 